\title{
Influence of the palm tree species on the variability of Rhodnius nasutus Stål, 1859 (Hemiptera, Reduviidae, Triatominae)
}

\author{
Fernando Braga Stehling Dias ${ }^{a}$, Alexandre Silva de Paula ${ }^{\mathrm{b}}$, Carlota Josefovicz Belisário ${ }^{\mathrm{a}}$, \\ Marcelo Gustavo Lorenzo ${ }^{a}$, Cláudia Mendonça Bezerra ${ }^{c}$, Myriam Harry ${ }^{\mathrm{d}}$, Liléia Diotaiuti ${ }^{\mathrm{a}, *}$

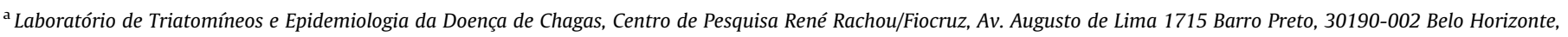 \\ MG, Brazil

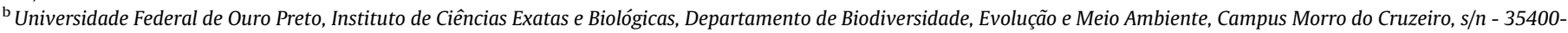 \\ 000 Ouro Preto, MG, Brazil

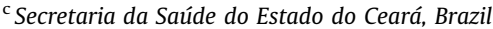 \\ ${ }^{\mathrm{d}}$ LEGS, CNRS, 91198 Gif-sur-Yvette Cedex E' Université Paris sud-11, France
}

\section{A R T I C L E I N F O}

\section{Article history:}

Received 24 November 2010

Received in revised form 31 January 2011

Accepted 8 February 2011

Available online 16 February 2011

\section{Keywords:}

Rhodnius nasutus

Ceará

Palm trees

Morphometry

Microclimatic data

Microsatellites

\begin{abstract}
A B S T R A C T
This work evaluated the occurrence and genetic structure of Rhodnius nasutus sampled in two sites using morphometry and microsatellites. These sites, presented distinct abiotic features and palm trees: (i) nine Attalea speciosa palm trees, so called babaçu, were sampled from the Meruoca Mountain Ridge, a sloping region of reminiscent forest in the state of Ceará, Brazil, and (ii) 17 Copernicia prunifera palm trees, so called carnaúba, were sampled in the scrub savanna region (Sobral district) that surrounds the mountain ridge. Of the twenty-six palm trees dissected, $70.6 \%$ of carnauba and $88.9 \%$ of babaçu were infested by $R$. nasutus. The micro-climatic data where $R$. nasutus were sheltered demonstrated that the babaçu and carnaúba palm trees presented significant differences $(p<0.05)$ in relation to the external environment, except for temperature and relative humidity regulation, suggesting that the architecture of the babaçu crown keeps a more stable micro-environment. The morphometric studies of the F1 generation demonstrated that insects from the babaçu $(A$. speciosa) were significantly larger $(p=0.000)$ than those collected in carnaúba ( $C$. prunifera) palm trees. Also, microsatellite analysis demonstrated a high genetic differentiation between the two groups of $R$. nasutus $\left(R_{\mathrm{st}}=-0.77\right)$. Our results suggest that the difference in size between the populations is probably related to an incipient process of genetic drift in populations associated to each palm tree, probably also driven by the different climatic features observed in these micro-environments.
\end{abstract}

(c) 2011 Elsevier B.V. All rights reserved.

\section{Introduction}

The Triatominae of the Rhodnius Stål genus are generally associated with birds' nests and different species of palm trees (Lent and Wygodzinsky, 1979). Rhodnius nasutus Stål, 1859 has a distribution restricted to the Northeast of Brazil, an area composed of a semi-arid biome called Caatinga (Carcavallo et al., 1998). This Triatominae is closely related to the carnaúba palm tree (Copernicia prunifera), which is characteristic of this biome (Alencar, 1987; Lucena and Lima-Borba, 1977; Sarquis et al., 2004), although the insect has also been found infesting other palm tree genera in the state of Ceará (Dias et al., 2008). Moreover, R. nasutus is found naturally infected by Trypanosoma cruzi and T. rangeli (Dias et al., 2007). The presence of this Triatominae is relatively frequent in artificial environments, especially in the peri-domicile area, being

\footnotetext{
* Corresponding author. Tel.: +55 31 33497762; fax: +55 3132953115 .

E-mail address: diotaiuti@cpqrr.fiocruz.br (L. Diotaiuti).
}

reported as the fourth most captured species by the Chagas Disease Control Program (PCDCh) in the Northeastern region and the third most captured in the state of Ceará. These data evidence the potential of $R$. nasutus as a Chagas disease vector in the Brazilian Caatinga.

The state of Ceará is almost completely covered by Caatinga vegetation (92\%). The Caatinga biome is of great biogeographical interest because it is related to the origin and the past of the forestal connection between the Amazon and the Atlantic Forest, which covered the whole east coast of South America (Behling et al., 2000). Among 15,500 and 11,500 years ago, South America underwent a period of greater humidity, allowing for a marked expansion of the gallery and mountain ridge forests. Later, due to coastal winds, the top of the mountain ridges and the slopes of the state of Ceará maintained the humidity conditions of the past, preserving the species of the humid forest and establishing what would become the so-called enclaves of the Brazilian Semi-Arid Humid Forest. As such, Ceará mountain ridges can present dense vegetation with residual elements of the Atlantic Forest and the 
Amazon, such as the babaçu palm tree (Attalea speciosa) (Monteiro and Kaz, 1994). Some studies have demonstrated that palm trees of this genus represent one of the main natural ecotopes of the Rhodnius species, presenting higher infection rates and triatominic density, in comparison to other palm trees (Romaña et al., 1999; Dias et al., 2008; Abad-Franch et al., 2009).

In this study, the infestation of babaçu palm trees by $R$. nasutus in the Meruoca Mountain Ridge, a forested enclave region in Ceará, is described. $R$. nasutus collected from carnaúba palm trees, derived from the Caatinga that surrounds the Meruoca Mountain Ridge, were compared to specimens captured from babaçu palms occurring in this region. The comparisons were performed by morphometric analysis. We also evaluate the genetic structure of both groups of $R$. nasutus with microsatellite markers with specimens from the first generation of $R$. nasutus obtained by laboratory rearing. In addition, the micro-climatic characteristics of both species of palm trees were analyzed and the relevance of temperature and relative humidity, as potential promoters of the observed variances between the populations of $R$. nasutus in both palm trees, were examined.

\section{Materials and methods}

\subsection{Sampling of R. nasutus}

The occurrence of $R$. nasutus was comparatively studied between the Meruoca Mountain Ridge, in the municipal district of Meruoca (S3 $31^{\prime} 39^{\prime \prime} / \mathrm{W} 40^{\circ} 25^{\prime} 50^{\prime \prime}, 650 \mathrm{~m}$ ), which is densely populated by babaçu palm trees, and the scrub savanna region that surrounds this mountain ridge, in the municipal district of Sobral $\left(\mathrm{S}^{\circ} 47^{\prime} 42^{\prime \prime} / \mathrm{W} 40^{\circ} 23^{\prime} 45^{\prime \prime}, 90 \mathrm{~m}\right)$, where there are an extensive amount of carnaúba palm trees (Figs. 1 and 2). Two captures were performed in 2003. The first sampling occurred between July 19 th and 23rd, representing the humid period or the rainy season.

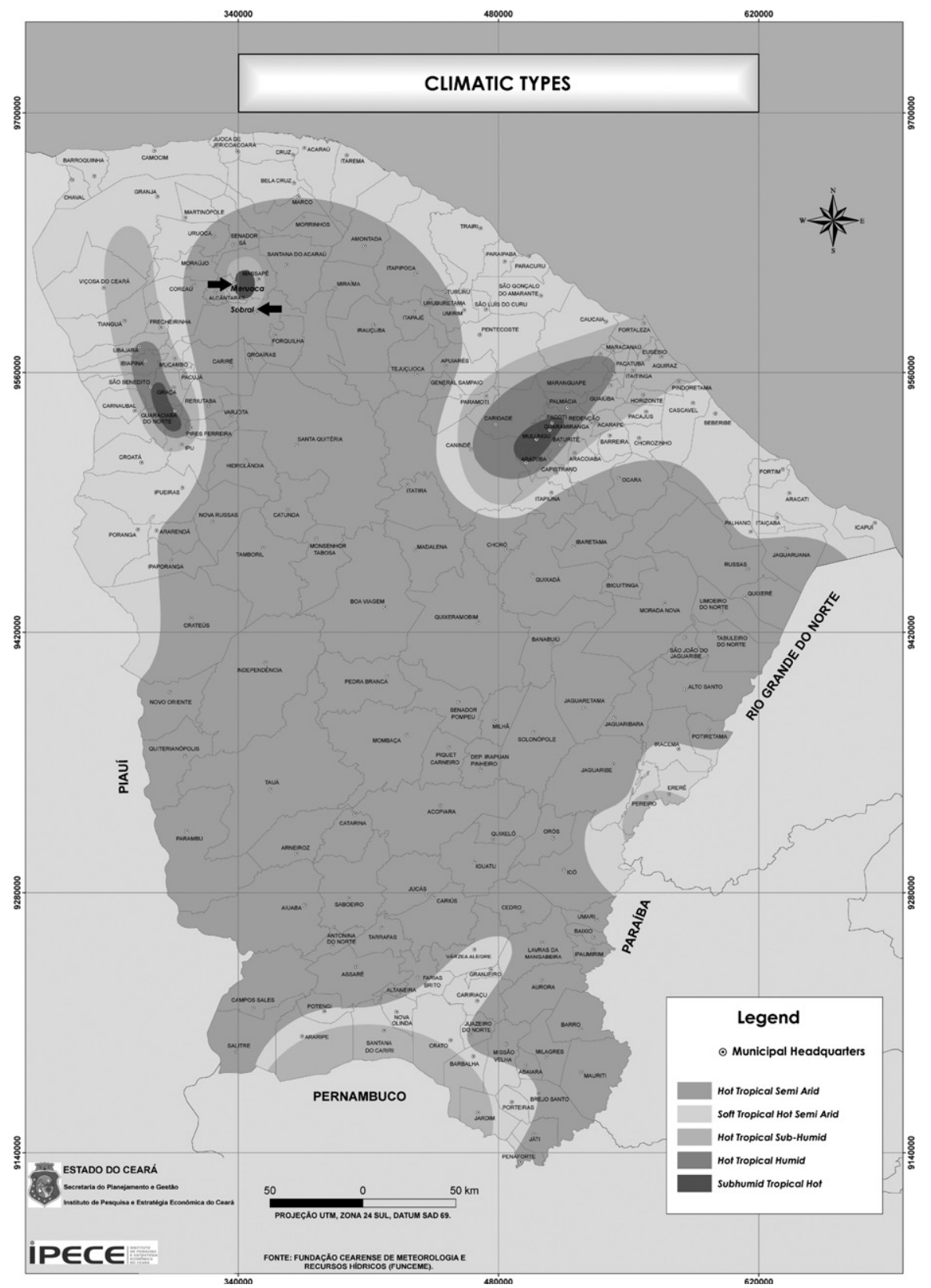

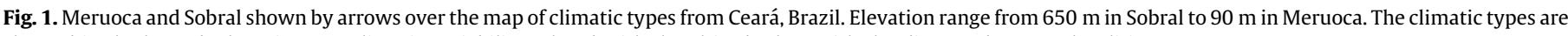
showed in the legend. There is more climatic variability related with the altitude than with the distance between localities. 

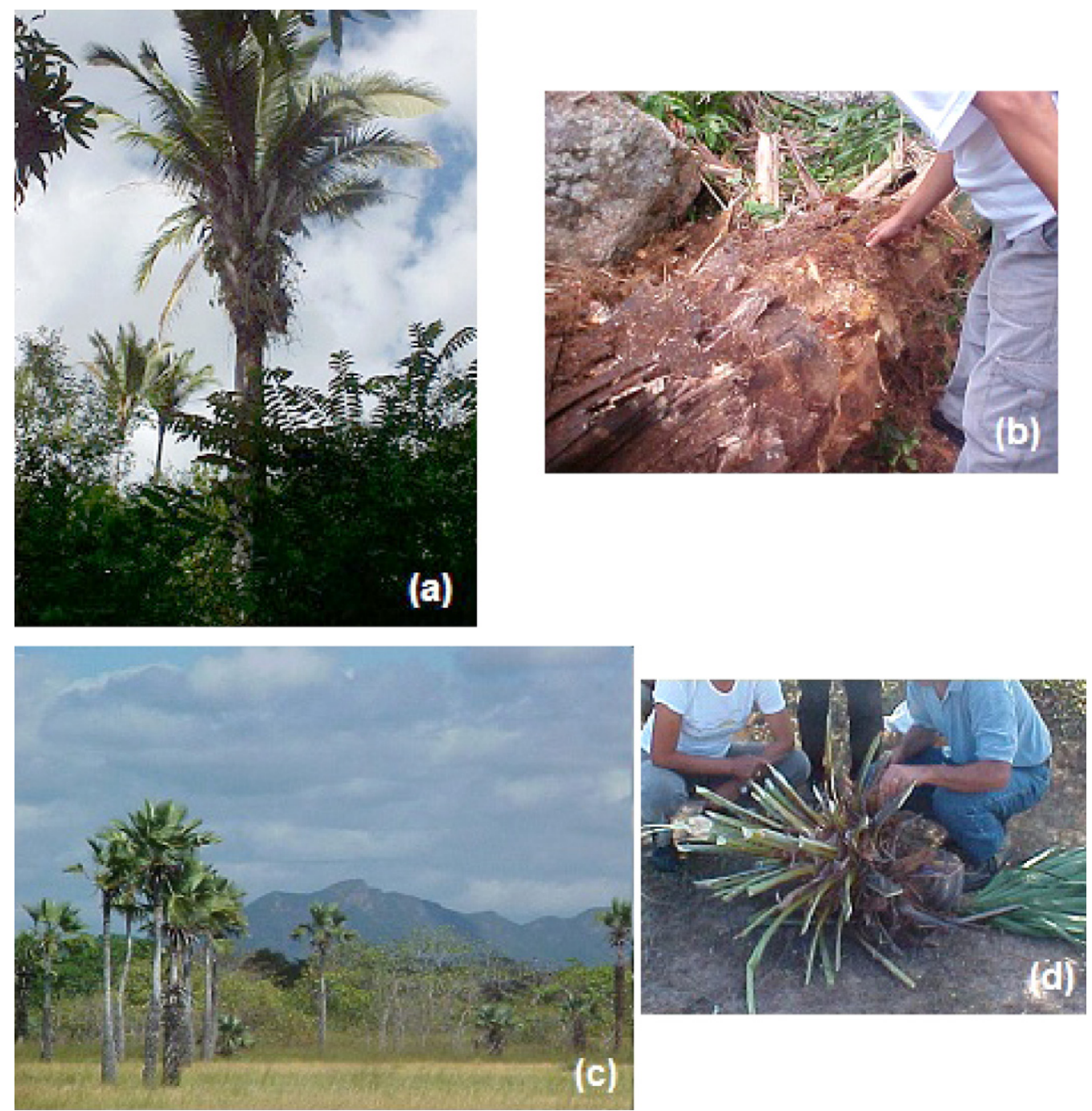

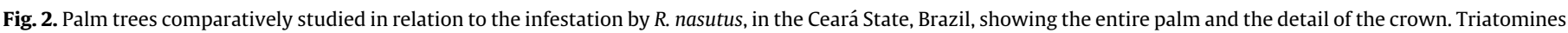
were found in areas where the leaves overlap. (a) and (b) Babaçu palm; (c) and (d) carnaúba palm.

The second sampling was performed between November 17th and $21 \mathrm{st}$, corresponding to the dry period or dry season. The methodology proposed by Diotaiuti and Dias (1984) was used for the collection of $R$. nasutus, after authorization by IBAMA (authorization number 007/2002-COMAF; process 02001.001333/ 02-71). The palm trees were cut down and dissected for insects. The triatomines collected were taken to the laboratory for constitution of colonies, to be used in the molecular and morphometric analysis. The founder colony was obtained from fertilized females collected in the field, inside the leaves of the palm trees, or fertilized by males filed in the laboratory. The colony was reared under the same environmental condition and food source. The average temperature was $24-26{ }^{\circ} \mathrm{C}$ and the mean humidity $70 \%$.

\subsection{Microclimatic data}

The registration of temperature and relative humidity of the axils of palm trees' leaves, which is the shelter for R. nasutus, was measured with programmed Hobo sensors (Hobo ${ }^{\circledR}$ RH, Temp, Light External - Onset Computer Corporation). During each capture period or season (July and November), the micro-climatic data were registered in three babaçu ( $A$. speciosa) and three carnaúba palm trees ( $C$. prunifera). A reference sensor was placed in the external environment close to the palm trees and under the shadow. The Hobo ${ }^{\circledR}$ readings were performed during three consecutive days, registering the temperature and relative humidity data at 15 min intervals. For data analysis, the mean values of the three palm trees from each species were used. The mean values of temperature and relative humidity of each palm tree species were compared to the values of the reference Hobo ${ }^{\circledR}$ sensors through a paired $t$ test (Quinn and Keough, 2002). The inferior (25\%) and superior (75\%) percentiles of the reference sensors' measures were also compared to the palm trees' values, through a paired $t$ test, in order to evaluate the variations of temperature and relative humidity extremes of babaçu and carnaúba species.

\subsection{Morphometric analysis}

Morphometric studies were carried out on reared insects from the F1 generation - 15 females and 15 males from Meruoca (babaçu) and 15 females and 15 males from Sobral (carnaúba). As per the methodology of Dujardin et al. (1998), six head measurements were taken from each specimen using an image analyzer system (KONTRON KS300): width of anteclypeus (AC), length of antenniferous tubercle (AT), anteocular distance (AO), external distance between ocelli (EO), external distance between 


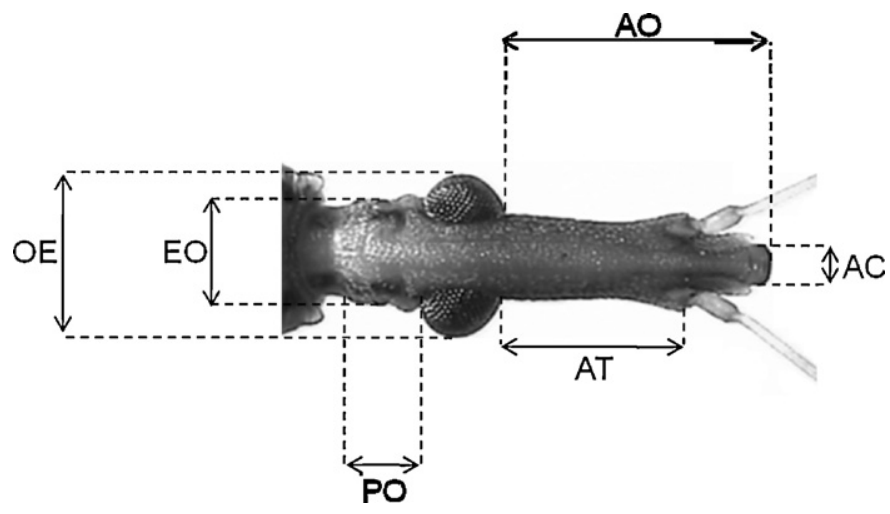

Fig. 3. Head of a $R$. nasutus indicating the measures used for the morphometric analysis. AC: width of anteclypeus; AT: length of antennal tubercle; AO: anteocular distance; EO: external distance between ocelli; OE: external distance between eyes; PO: postocular distance excluding neck.

eyes (OE), and post ocular distance excluding neck (PO) (Fig. 3). The measurements were made using the KS/300 computerized image analysis system, with a Carl Zeiss KONTRON Electronic GMBH model at a magnification of $20 \times$. Observations were tested for normality using the Kolmogorov-Smirnov Test and were also used for multivariate analysis (discriminant analysis). Homogeneity of variances (homoscedasticity) was tested using the Levene Statistic. Wilks' Lambda was performed to test the null hypothesis that the groups have the same mean discriminant function scores and to conclude that the model is discriminating (Wilks, 1932). Pairwise group comparisons were done using Mahalanobis distances. All calculations for multivariate analysis were made using the software package SPSS 16.0. The Kolmogorov-Smirnov Test was done using the software package StatView 5.0.1.

\subsection{Molecular analysis - microsatellites}

The genomic DNA of $R$. nasutus was extracted from one leg of a first generation adult insect, obtained in the laboratory. For the extraction, a simplified protocol with STE solution $(0.1 \mathrm{M} \mathrm{NaCl}$; $10 \mathrm{mM}$ Tris/HCl pH 8.0; 1 mM EDTA pH 8.0) was used according to the technique standardized by Balbino et al. (2006).

We used 12 females and 12 males from each group (babaçu and carnaúba) and tested 10 loci designed for $R$. prolixus (Harry et al., 2008), six of which are genotyped (R4, R8, R17, R26, R30 and R31). The "forward" primer of each pair marked the $5^{\prime}$ extremity with fluorescein.

The PCR amplifications were performed in a Mastercycler Gradient $^{\mathrm{TM}}$ (Eppendorf, Germany) thermo-cycler in a total volume of $15 \mu \mathrm{L}$, containing $1 \mu \mathrm{L}$ of $10 \times$ Taq Reaction buffer $(200 \mathrm{mM}$ Tris $\mathrm{pH} 8.4,500 \mathrm{mM} \mathrm{KCl}), 0.4$ or $0.6 \mu \mathrm{L}$ of $50 \mu \mathrm{M} \mathrm{MgCl}_{2}, 20 \mu \mathrm{M}$ of each dNTP, $10 \mathrm{mM}$ of each primer, $2 \mu \mathrm{L}$ of genomic DNA and $0.5 \mathrm{U}$ Taq DNA Polymerase (Invitrogen). The PCR cycle consisted of an initial denaturation at $95{ }^{\circ} \mathrm{C}$ for $5 \mathrm{~min}$, followed by 30 cycles at $95^{\circ} \mathrm{C}$ for $30 \mathrm{~s} ; 52{ }^{\circ} \mathrm{C}$ for $30 \mathrm{~s}$ and $72{ }^{\circ} \mathrm{C}$ for $30 \mathrm{~s}$ and final extension at $72{ }^{\circ} \mathrm{C}$ for $5 \mathrm{~min}$.

The amplified products were visualized in a polyacrylamide gel at $8 \%$ in a mini-gel system (BIO-RAD), stained with $0.2 \%$ silver nitrate. Then, the PCR products were diluted at 1:10 in Milli-Q water and genotyped in a MEGABace (Amersham Biosciences) sequencer. The size of the PCR products was estimated in comparison with a standard size marker (ET-400, GE Health Care) and the genotypes were read using the software Fragment Profiler $^{\mathrm{TM}}$. The genetic variability between populations and among individuals was calculated by AMOVA test and using $R_{\mathrm{st}}$ index like the method of distances. This procedure was carried out using the software Arlequin 3.1.

\section{Results}

\subsection{Index of infestation and population density}

Twenty-six palm trees were dissected, 17 carnaúbas ( $A$. speciosa) and nine babaçus ( $C$. prunifera). All palm trees were adult specimens, with an average size of $9.6 \mathrm{~m}$ for babaçu and $7.8 \mathrm{~m}$ for carnaúba. The global infestation index was of $76.9 \%$. In total, 12 carnaúbas and eight babaçus were infested by $R$. nasutus, with a global infestation index of $70.6 \%$ and $88.9 \%$, respectively. All of the 87 collected Triatominae were identified as $R$. nasutus according to the Lent and Wygodzinsky (1979) identification keys and compared with the reference specimens from the Laboratorio de Triatomíneos e Doença de Chagas (Cento de Pesquisa René Rachou - FIOCRUZ). The population structure of the insects captured in carnaúbas was significantly different between the dry and rainy seasons $(p=0.000028)$, with total predominance of immature forms (nymphs) in the dry season. However, the same seasonal variation did not occur within the Triatominae collected in the babaçu palm trees $(p=0.60)$. No difference was observed in the infestation rate between the dry and rainy seasons $(p=0.4025)$ or among the infestation of babaçu and carnaúba palm trees $(p=0.3798)$. The infestation and population density data are shown in Table 1.

\subsection{Microclimatic data}

The highest temperatures were registered in November, in Sobral, both on the carnaúba and on the reference sensors. The highest relative humidity was observed in babaçu in Meruoca, both in July and in November. These results indicate that the carnaúba has a warmer and drier environment, whereas in the babaçu it is more humid (Figs. 4 and 5).

Figs. 4 and 5 present box plots for temperature and relative humidity of the palm trees. As seen in these figures, the babaçu presents lower amplitudes of temperature and relative humidity variations than the carnaúba. Furthermore, the babaçu presented

Table 1

Number of infested palms and R. nasutus captured in the carnaúbas from Sobral (Caatinga) and the babaçus from Meruoca (forest reminiscent), Ceará, 2003.

\begin{tabular}{|c|c|c|c|c|c|c|c|c|}
\hline & \multicolumn{4}{|l|}{ Carnaúba palm } & \multicolumn{4}{|l|}{ Babaçu palm } \\
\hline & \multirow[t]{2}{*}{ Searched/infested } & \multicolumn{3}{|c|}{ Collected triatomines } & \multirow[t]{2}{*}{ Searched/infested } & \multicolumn{3}{|c|}{ Collected triatomines } \\
\hline & & $\mathrm{N}$ & Ad & Total & & $\mathrm{N}$ & Ad & Total \\
\hline $\begin{array}{l}\text { Rainy period } \\
\text { (July) }\end{array}$ & $\begin{array}{l}9 / 8 \\
(88.9 \%)\end{array}$ & $\begin{array}{l}14 \\
(66.7 \%)\end{array}$ & $\begin{array}{l}7 \\
(33.7 \%)\end{array}$ & 21 & $\begin{array}{l}4 / 3 \\
(75 \%)\end{array}$ & $\begin{array}{l}24 \\
(92.3 \%)\end{array}$ & $\begin{array}{l}2 \\
(7.7 \%)\end{array}$ & 26 \\
\hline $\begin{array}{l}\text { Dry period } \\
\text { (November) }\end{array}$ & $\begin{array}{l}8 / 4 \\
(50 \%)\end{array}$ & $\begin{array}{l}28 \\
(100 \%)\end{array}$ & 0 & 28 & $\begin{array}{l}5 / 5 \\
(100 \%)\end{array}$ & $\begin{array}{l}10 \\
(83.3 \%)\end{array}$ & $\begin{array}{l}2 \\
(16.7 \%)\end{array}$ & 12 \\
\hline Total & $\begin{array}{l}17 / 12 \\
(70.6 \%)\end{array}$ & $\begin{array}{l}42 \\
(82.4 \%)\end{array}$ & $\begin{array}{l}7 \\
(17.6 \%)\end{array}$ & 49 & $\begin{array}{l}9 / 8 \\
(88.9 \%)\end{array}$ & $\begin{array}{l}34 \\
(89.5 \%)\end{array}$ & $\begin{array}{l}4 \\
(10.5 \%)\end{array}$ & 38 \\
\hline
\end{tabular}

N: nymphs; Ad: adults. 


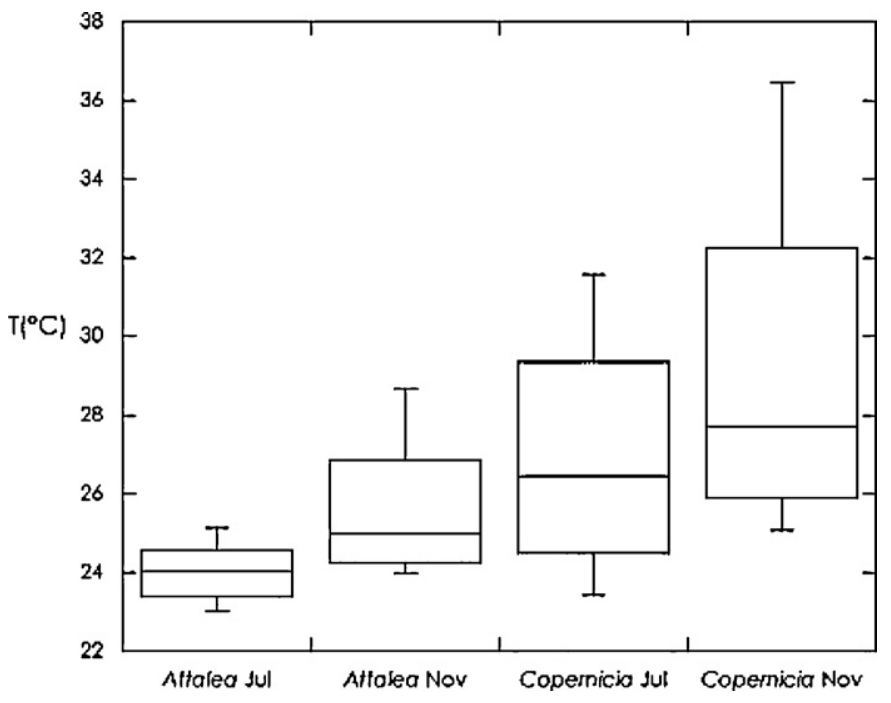

Fig. 4. Boxplot comparing the temperature variations in the axil leaf of the studied palm trees (Attalea speciosa - babaçu and Copernicia prunifera - carnaúba). There were significant differences in all of the mean values obtained from A. speciosa (dry and rainy season) and from $C$. prunifera in both dry and rainy season by paired sample $t$ test $(\mathrm{df}=95 ; p=0.000)$.

lower mean temperature values than the carnaúba, as well as a higher relative humidity (Figs. 4 and 5 ).

When the $25 \%$ and $75 \%$ percentiles were analyzed, all values differed from the respective reference sensors of babaçu and carnaúba in the months of July and November $(p=0.0000)$. The comparisons of relative humidity, obtained by the paired $t$ test, indicated significant differences between the external environment and the axils of the babaçu and carnaúba $(p \leq 0.0002)$, the exception being for the babaçu in November $(p=0.9270)$ and the $75 \%$ percentile of the carnaúba in November $(p=0.1603)$.

Figs. 6 and 7 present graphs for temperature and relative humidity variations between the studied palm trees and the sensors of the external environment. As shown in these figures, the records of temperature and relative humidity differ between the palm trees and their respective reference sensors. However, the relative humidity in July demonstrated little variation between the

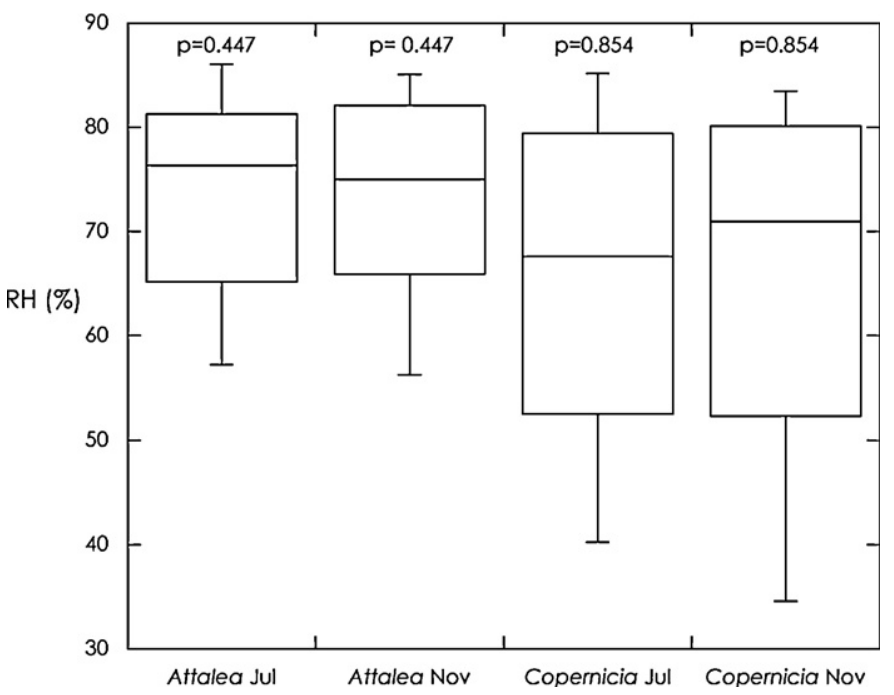

Fig. 5. Boxplot comparing the relative humidity variations in the axils of the studied palm trees (Attalea speciosa - babaçu and Copernicia prunifera - carnaúba). There were no significant differences in the mean value obtained from A. speciosa (dry and rainy season) and from $C$. prunifera (dry and rainy season) by paired sample $t$ test (respectively $t=0.764 ; \mathrm{df}=95 ; p=0.447$ and $t=-0.184 ; \mathrm{df}=95 ; p=0.854$ ). external environment and the axils of palm trees. Moreover, there appears to be a tendency for a higher variation at the extremes of temperature and relative humidity between the palm trees' axils, where $R$. nasutus are sheltered, and the external environment.

\subsection{Morphometry}

The homoscedasticity (Levene Statistic) and Wilks' Lambda tests showed that the model is discriminating (Table 2). Eigenvalues from the first 3 canonical discriminant functions used in the analysis showed that function 1 explained $88.582 \%$ of the variance (Table 3). Mahalanobis distances performed to compare the four populations showed that males from the babaçu and females from the carnaúba did not differ statistically considering the six head measures used in this study (Table 4, Fig. 8). The discriminant analysis also showed that when the $R$. nasutus populations were compared using males and females from each palm tree, Mahalanobis distances corroborate that the populations differed among each site (Table 5). Also, the specimens from each palm species (A. speciosa and $C$. prunifera) showed significant difference when comparing males and females together with pairwise group comparisons based on Mahalanobis distances $(\mathrm{df}=1,58 ; p=0.000)$ - Table 5 .

\subsection{Microsatellites}

Ten microsatellite primers designed for R. prolixus (Harry et al., 2008) were tested in $R$. nasutus, but the amplification of four out of the ten primers was poor in the preliminary PCR (data not shown). In the carnaúba population, the six microsatellites used presented 19 alleles while the babaçu population presented 15 alleles. The loci used were polymorphic in the two populations tested, except for the R8 locus in the babaçu population and the R31 locus in the carnaúba population.

The babaçu population presented a mean of three alleles per locus (varying between two and four alleles) and the carnaúba population presented a mean of 3.6 alleles per locus (varying between two and six alleles) (Table 6). Moreover, we found 25 haplotypes for the carnaúba population and 17 for the babaçu population. Furthermore, five unique alleles in the babaçu population and six in the carnaúba population were observed. The $R_{\mathrm{st}}$ index showed great variability (0.7674) when comparing the two populations and among individuals within populations (0.1736). $H_{\mathrm{o}}$ ranged from 0 to 0.47619 and $H_{\mathrm{e}}$ from 0 to 0.73403 . The Hardy-Weinberg equilibrium suggests a deficit of heterozygosity, indicating population subdivision or the presence of null alleles. Table 6 presents a global result of microsatellites analysis.

\section{Discussion}

Palm trees are considered the natural ecotope of triatomines of the Rhodnius genus, except for $R$. domesticus Neiva and Pinto, 1923 which is associated with bromeliads (Lent and Wygodzinsky, 1979). R. nasutus is an autochthonous Brazilian triatomine species, considered a vector of secondary importance in the transmission of human Chagas disease (Alencar, 1987). In recent years, $R$. nasutus has been the fourth most captured species of Triatominae in the state of Ceará, according to data from the Chagas Disease Control Program (PCDCh). Although data from PCDCh indicate that insects were not found inside houses, the presence of infected $R$. nasutus with $T$. cruzi in the peri-domicile has been constant, probably due to the proximity of the palm trees to the houses, causing these insects to be attracted at night by the houses' lights when seeking food (Sarquis et al., 2004; Lima et al., 2008).

Although Alencar (1987) has already reported the infestation of $R$. nasutus in the babaçu palm, most of the studies so far were 

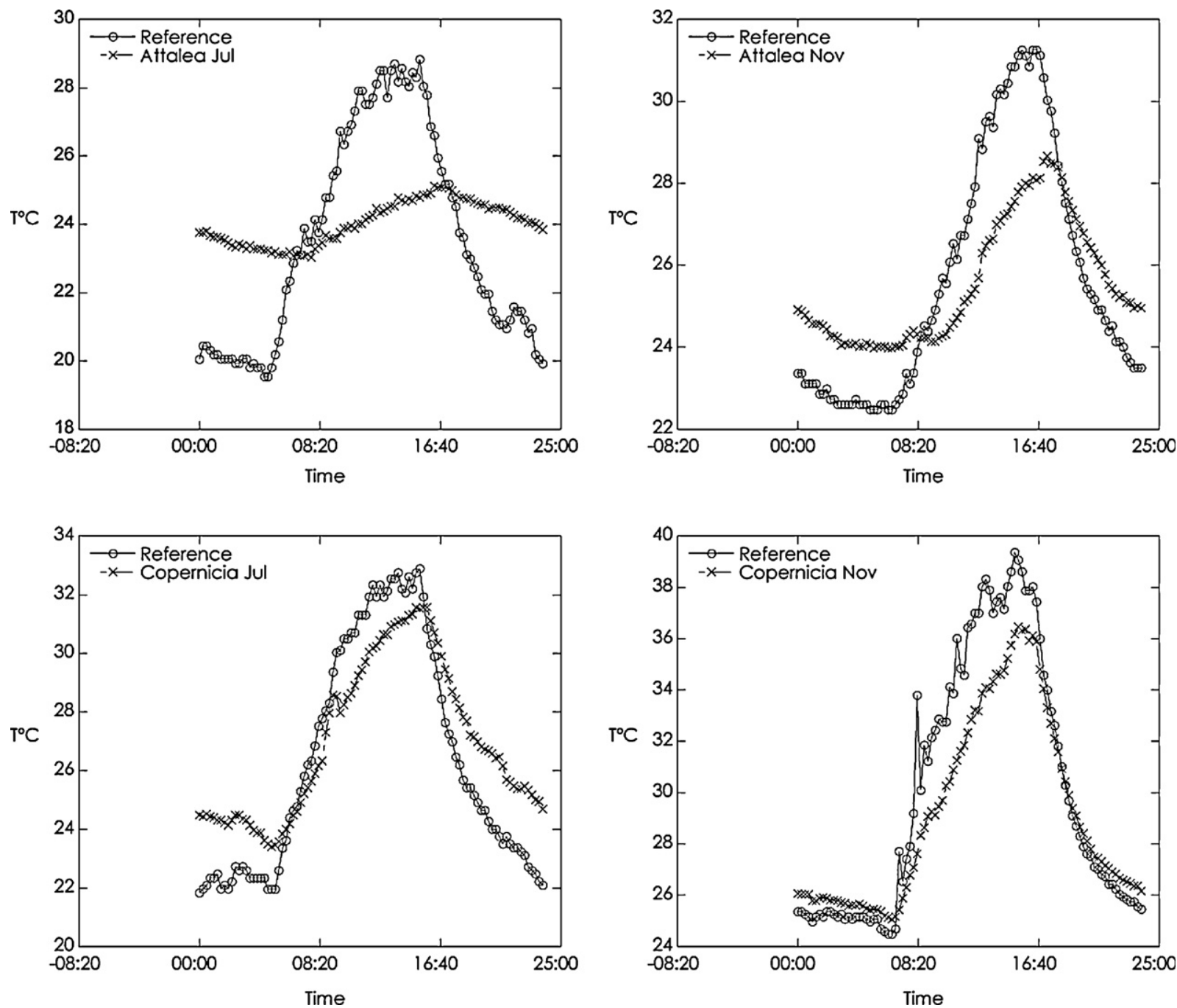

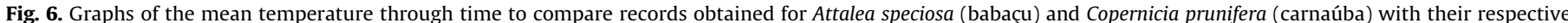

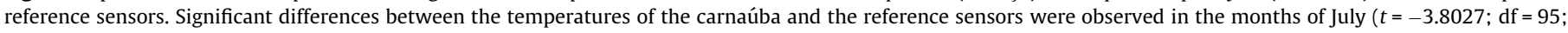
$p=0.0003)$ and November $(t=5.0838 ; \mathrm{df}=95 ; p=0.0000)$.

performed collecting the Triatominae from the carnaúba palm trees, which is considered its natural ecotope. However, Dias et al. (2008) investigated the Chapada do Araripe region, in the south of Ceará State, and studied the ecology of this species. These results demonstrated that, besides the carnaúba, $R$. nasutus takes shelter in other palm tree species, and reported for the first time $R$. nasutus infestation in Acrocomia, Syagrus and Mauritia palm tree genera. Although the number of insects collected between the babaçu palm tree and the carnaúba was quite different (224 and 24, respectively), no difference was found in the infestation rate among the species of palm trees investigated. In this same study, Dias et al. (2008) used instantaneous data of temperature in the leaves' axils, at the moment of dissecting the palm trees, and the results regarding the micro-climatic data demonstrated that the babaçu palm tree has a lower temperature variation, with a more stable micro-climate, whereas in the carnaúbas the thermal amplitude was clearly higher, corroborating the microclimatic results presented here.

The micro-climatic data presented in this study indicated that the carnaúba and babaçu palm trees have different characteristics in relation to the external environment. The variation of temperature in the babaçu crowns was greatly damped during the dry season, whereas during the humid season the temperature range was higher. These results indicate that the regulation of the carnaúba's relative humidity and temperature is lower when compared to the babaçus, probably due to its smaller crown and complexity at the base of the leaves. In the babaçus, the architecture of the crown seems to decrease the variation of the

Table 2

Wilks' Lambda to test the null hypothesis that the groups have the same mean discriminant function scores. The analysis was discriminant $(p=0.000)$.

\begin{tabular}{lllll}
\hline Test of function(s) & Wilks' Lambda & Chi-square & df & Sig. \\
\hline 1 through 3 & 0.215 & 82.997 & 18 & 0.000 \\
2 through 3 & 0.746 & 15.818 & 10 & 0.105 \\
3 & 0.908 & 5.229 & 4 & 0.265 \\
\hline
\end{tabular}

Table 3

Eigenvalues from the first 3 canonical discriminant functions used in the analysis.

\begin{tabular}{llccl}
\hline Function & Eigenvalue & \% of variance & Cumulative \% & Canonical correlation \\
\hline 1 & 2.470 & 88.582 & 88.582 & 0.844 \\
2 & 0.217 & 7.771 & 96.353 & 0.422 \\
3 & 0.102 & 3.647 & 100.000 & 0.304 \\
\hline
\end{tabular}



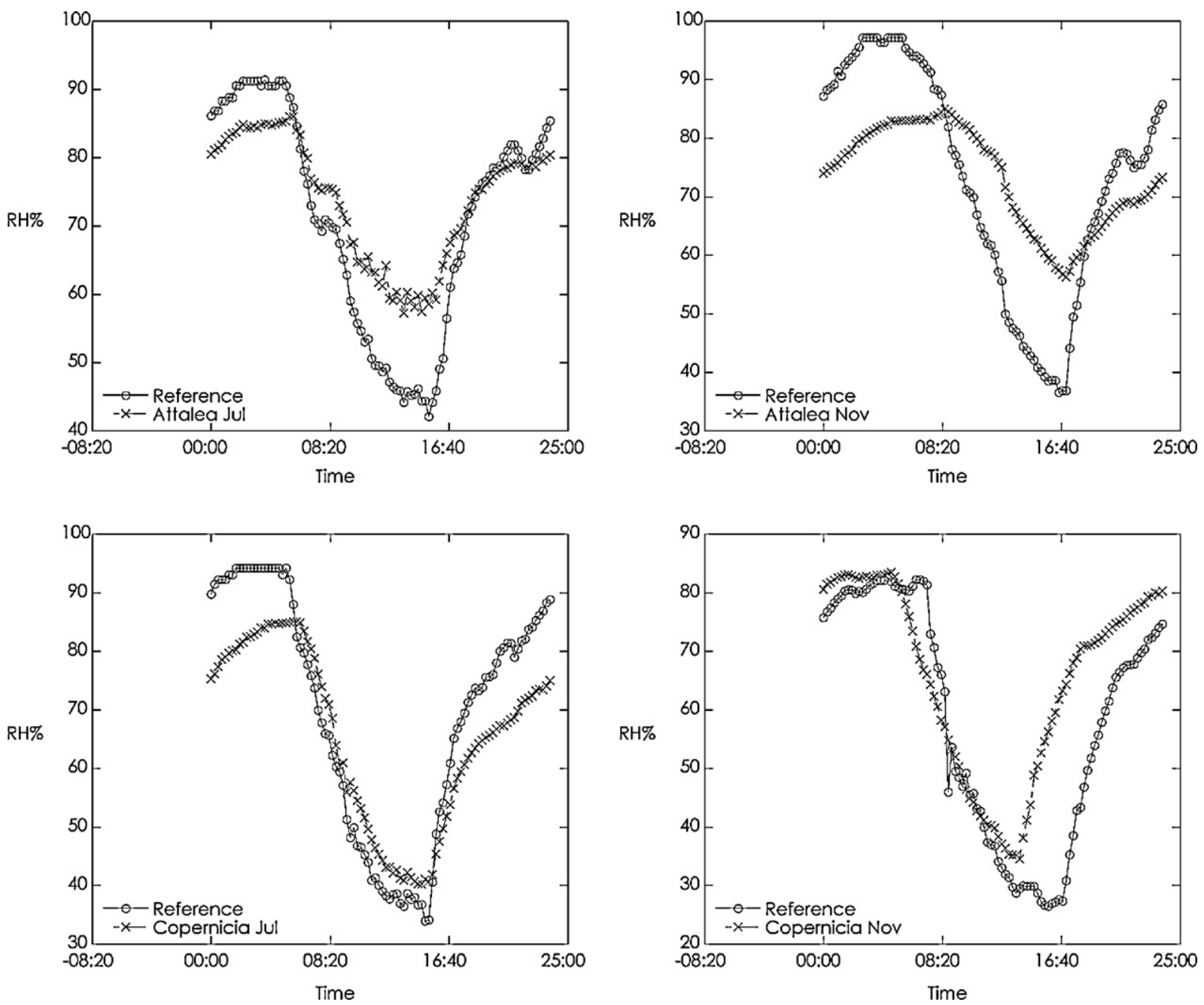

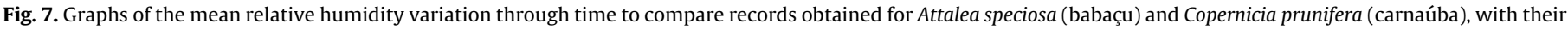

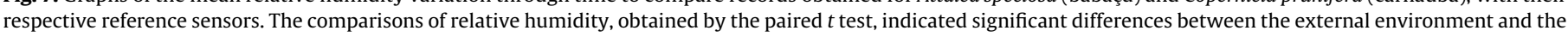
axils of the babaçu and carnaúba $(p \leq 0.0002)$, except for the babaçu in November $(p=0.9270)$.

climatic parameters in the interior where R. nasutus are sheltered, offering micro-environments with moderate relative humidity and temperature means, within highly stable variation margins for this triatomines.

Some studies indicate that the palm trees of the genus Attalea are the main ecotope for the species of the genus Rhodnius. For example, in southern Ceará State, Dias et al. (2008) point to the

\section{Table 4}

Pairwise group comparisons based on Mahalanobis distances ( $d f=1,56)$. Populations 2 (males from the babaçu) and 3 (females from the carnaúba) did not differ statistically $(p$ value $=0.972)$.

\begin{tabular}{llrlll}
\hline Population & & 1 & 2 & 3 & 4 \\
\hline 1 & F & & & & \\
& Sig. & & & & \\
2 & F & 38.226 & & \\
3 & Sig. & 0.000 & & & \\
& F & 38.660 & 0.001 & & \\
4 & Sig. & 0.000 & 0.972 & & \\
& F & 85.357 & 9.340 & 9.127 \\
& Sig. & 0.000 & 0.003 & 0.004
\end{tabular}

Population: 1 =females from the babaçu; 2 =males from the babaçu; 3 =females from the carnaúba; 4 =males from the carnaúba. babaçu palm tree as a main ecotope for $R$. nasutus. Attalea palm trees have relatively closed crowns, permitting a great diversity of vertebrates that serve as food sources for the triatomines and maintain the T. cruzi cycle in the sylvatic environment.

In the babaçus, the presence of possible feeding sources was observed during insect capture expeditions, including rodents, birds and lizards. This, however, was not observed with the carnaúbas. Babaçu palm trees have many leaves with large foliar sheaths that overlap the stem and form a great crown. The carnaúbas, on the other hand, have a relatively small crown with frond insertion-patterns that allow solar radiation to penetrate the crown, corresponding to less stable shelters for insects. The architecture of the palm trees' crowns is a crucial factor for the shelter of triatomines, as well as for the maintenance and microclimatic stability (Dias et al., 2008). In fact, the architecture of the babaçu palm tree crown, that is the way the leaves' sheaths are inserted into the stem, is related to the number of feeding sources for the triatomines, including large animals like Tamandua tetradactyla (Dias et al., 2010), as well as the density and biological diversity of $R$. nasutus.

When evaluating the size of the insects (F1 generation) from the babaçus and carnaúbas, the morphometric results demonstrated a clear sexual dimorphism in both populations, being that $R$. nasutus 


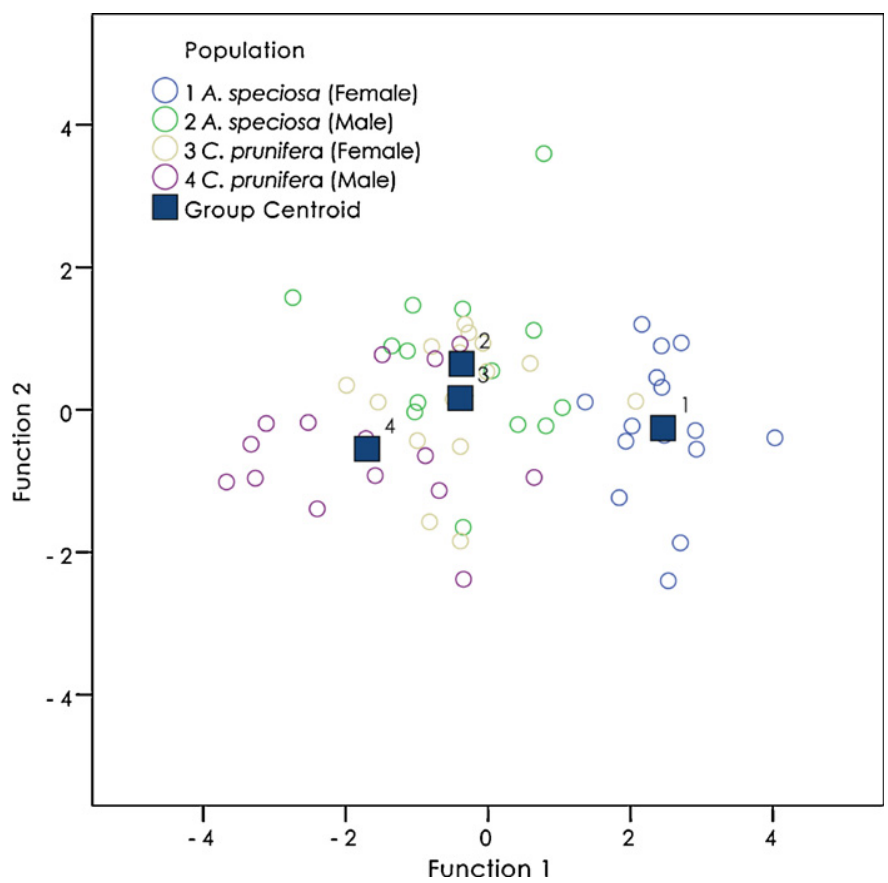

Fig. 8. Group centroid derived from morphometric analysis demonstrating that populations 2 (males from the babaçu) and 3 (females from the carnauba) did not differ.

Table 5

Pairwise group comparisons based on Mahalanobis distances ( $\mathrm{df}=1,58$ ). Populations from the babaçu and carnaúba differ statistically $(p=0.000)$. Population 1 indicates females + males from the babaçu, and population 2 indicates females + males from the carnaúba.

\begin{tabular}{llrr}
\hline Population & & 1 & \multicolumn{1}{c}{2} \\
\hline 1 & F & & 24.132 \\
& Sig. & & 0.000 \\
2 & F & 24.132 & \\
& Sig. & 0.000 & \\
\hline
\end{tabular}

derived from the babaçus are larger than those from the carnaúbas. Lent and Wygodzinsky (1979) revised Triatominae systematics, showing that the females of this subfamily are normally larger than the males, despite the fact that some Triatominae species present larger males than females. Laboratory studies developed by these researchers demonstrated that the quantity of food available for nymphs influences the size of adults. In laboratory colonies the individuals tend to become progressively smaller, even if there is abundant food for the nymphs. These researchers, however, did not theorize the underlying cause for this phenomenon.

Adult individuals grown in high temperatures had smaller bodies and wings (Nijhout, 2003). Such reduction in size was associated to the decrease in the cells' size, as there were no variations in the number of cells that justified the reduction in size. Empirical evidences indicate that the environment can affect the body size of insects when grown in high temperatures or under reduced nutritional quality (Nijhout, 2003).

The founder colony was obtained from fertilized females collected in the field, inside the leaves of the palm trees, or fertilized by males filed in the laboratory. The colony was reared under the same environmental condition and food source. The average temperature was $24-26{ }^{\circ} \mathrm{C}$ and the mean humidity $70 \%$. It can be possible that the body sizes of the reared insects are genetically related because the rearing specimens showed differences in the mean body size when comparing specimens from A. speciosa and C. prunifera. Nijhout (2003) showed that the body size reduction of field insects could be spread to their offspring.

Our study showed this possible adaptation in the field, which means that $R$. nasutus is able to colonize houses from the palm tree where it lives, migrating from peri-domiciliary palm trees. This finding represents an important contribution to our understanding of the potential colonization of $R$. nasutus in the Caatinga biome.

Data obtained from microsatellite analysis demonstrate high population structuring between the babaçu and carnaúba groups. The $R_{\mathrm{st}}$ index was 0.77 and according to Wright (1978), this value represents high genetic divergence, probably related to geographic isolation. Observed heterozygosity was higher in the carnaúba population when compared with the babaçu population. Even though the number of trees sampled has been different ( 8 for babaçu and 12 for carnaúba), it cannot explain the lower variability within population observed for the babaçu population, since the number of adults collected in this palm tree was higher, and females might have been collected already fertilized. This result may be a consequence of the different architecture characteristics of each palm, which appear to make the carnaúba a less hospitable environment for the triatomines while the babaçus offer a more stable environment, with several possible feeding resources associated with triatomines.

Our results demonstrate that the babaçu and carnaúba's populations present high genetic isolation. Moreover the presence of animals co-inhabiting the palm trees with Triatominae, associated to the microclimatic data, could be fundamental factors for the size variation found in these insects.

Table 6

Characteristics of six microsatellite marker loci in R. nasutus.

\begin{tabular}{|c|c|c|c|c|c|c|}
\hline Locus & Num. alleles & $\begin{array}{l}H_{\mathrm{o}} \\
\text { Babaçu palm }\end{array}$ & $H_{\mathrm{e}}$ & Num. alleles & $\begin{array}{l}H_{\mathrm{o}} \\
\text { Carnaúba palm }\end{array}$ & $H_{\mathrm{e}}$ \\
\hline R4 & 4 & $0.30435^{*}$ & 0.34106 & 2 & 0.166667 & 0.15603 \\
\hline R8 & & Monomorphic locus & & 3 & 0.00000 & 0.00000 \\
\hline $\mathrm{R} 17$ & 3 & $0.26087^{*}$ & 0.23671 & 5 & $0.41176^{*}$ & 0.45098 \\
\hline R26 & 3 & $0.00000^{*}$ & 0.50709 & 6 & $0.47619^{*}$ & 0.73403 \\
\hline $\mathrm{R} 30$ & 2 & $0.00000^{*}$ & 0.29433 & 2 & 0.00000 & 0.00000 \\
\hline R31 & 3 & 0.00000 & 0.08156 & Monomorphic locus & & \\
\hline Mean & 3 & 0.11304 & 0.29215 & 3.6 & 0.21092 & 0.33133 \\
\hline S.D. & 0.707 & 0.15555 & 0.15493 & 1.817 & 0.22452 & 0.25858 \\
\hline
\end{tabular}

$H_{\mathrm{o}}=$ observed heterozygosity; $H_{\mathrm{e}}=$ expected heterozygosity.

Hardy-Weinberg test equilibrium showed significant heterozygosity deficits $(p<0.05)$. 


\section{Financial support}

This work was funded by FAPEMIG, CNPq and CPqRR-FIOCRUZ.

\section{Conflict of interest}

No conflict of interest related to this article for all authors.

\section{Ethical statement}

This study strictly followed the ethical codes of Brazil. The sampling was carried out in full compliance with the Brazilian laws (IBAMA authorization no: 007/2003-COMAF).

\section{Acknowledgments}

To the Secretaria de Estado da Saúde do Ceará for helping us to collect the insects. We thank Jordan Sky Oestreicher and Dra. Maria Victoria Periago for revising the paper.

\section{References}

Abad-Franch, F., Monteiro, F.A., Jaramillo, N., Gurgel-Gonçalves, R., Dias, F.B.S., Diotaiuti, L., 2009. Ecology, evolution and the long-term surveillance of vector-borne Chagas disease: a multi-scale appraisal of the tribe Rhodniini (Triatominae). Acta Trop. 110, 159-177.

Alencar, J.E., 1987. História Natural da Doença de Chagas no Ceará. Imprensa Universitária. Universidade Federal do Ceará, Brasil.

Balbino, V.Q., Coutinho-Abreu, I.V., Sonoda, I.V., Melo, M.A., Andrade, P.P., De Castro, J.A.F., Rebêlo, J.M., Carvalho, S.M.S., Ramalho-Ortigão, M., 2006. Genetic structure of natural populations of the sand fly Lutzomyia longipalpis (Diptera: Psychodidae) from the Brazilian northeastern region. Acta Trop. 98, 15-24.

Behling, H.A.R.Z.H.W., Pätzold, J., Wefer, G., 2000. Late quaternary vegetational and climate dynamics in northeastern Brazil, inferences from marine core GeoB 3104-1. Quaternary Sci. Rev. 19, 981-994.

Carcavallo, R.U., Curto De Casas, S.I., Sherlock, I.A., Galíndez Girón, I., Jurberg, J., Galvão, C., Mena Segura, C.A., Noireau, F., 1998. Distribuição geográfica e dispersão altitudinal. In: Cacavallo, R.U., Galíndez Girón, I., Jurberg, J., Lent org, H. (Eds.), Atlas of Chagas' disease vector in the Americas Fiocruz - Rio de Janeiro, vol. III. pp. 747-792.

Dias, F.B.S., Bezerra, C.M., Machado, E.M.M., Casanova, C., Diotaiuti, L., 2008 Ecological aspects of Rhodnius nasutus Stål, 1859 (Hemiptera: Reduviidae:
Triatominae) in palms of the Chapada do Araripe in Ceará, Brazil. Mem. Inst. Oswaldo Cruz 103, 824-830.

Dias, F.B.S., Diotaiuti, L., Romanha, A.J., Bezerra, C.M., Machado, E.M.M., 2007. First report on the occurrence of Trypanosoma rangeli Tejera, 1920 in the state of Ceará, Brazil, in naturally infected triatomine Rhodnius nasutus Stål, 1859 (Hemiptera, Reduviidae, Triatominae). Mem. Inst. Oswaldo Cruz 102, 643-645.

Dias, F.B.S., Quartier, M., Romaña, C.A., Diotaiuti, L., Harry, M., 2010. Tamandua tetradactyla Linnaeus, 1758 (Myrmecophagidae) and Rhodnius robustus Larrousse, 1927 (Triatominae) infection focus by Trypanosoma rangeli Tejera, 1920 (Trypanosomatidae) in Attalea phalerata Mart. ex Spreng (Arecaceae) palm tree in the Brazilian Amazon. Infect. Genet. Evol. 10, 1278-1281.

Diotaiuti, L., Dias, J.C.P., 1984. Ocorrência e biologia do Rhodnius neglectus Lent, 1954 em macaubeiras da periferia de Belo Horizonte-MG. Mem. Inst. Oswaldo Cruz 79, 293-301.

Dujardin, J.P., Schofield, C.J., Tibayrenc, M., 1998. Population structure of Andrean Triatoma infestans: allozyme frequencies and their epidemiological revelance. Med. Vet. Entomol. 12, 20-29.

Harry, M., Roose, C.L., Vautrin, D., Noireau, F., Romaña, C.A., Solignac, M., 2008. Microsatellite markers from the Chagas disease vector, Rhodnius prolixus (Hemiptera, Reduviidae), and their applicability to Rhodnius species. Infect. Genet. Evol. 8, 381-385.

Lent, H., Wygodzinsky, P., 1979. Revision of the Triatominae (Hemiptera, Reduviidae), and their significance as vectors of Chagas' disease. Bull. Am. Mus. Nat. Hist. 163, 127-520 (New York).

Lima, M.M., Coutinho, C.F.S., Gomes, T.F., Oliveira, T.G., Duarte, R., Borges-Pereira, J. Bóia, M.N., Sarquis, O., 2008. Risk presented by Copernicia prunifera palm trees in the Rhodnius nasutus distribution in a Chagas disease-endemic area of the Brazilian northeast. Am. J. Trop. Med. Hyg. 79, 750-754.

Lucena, D.T., Lima-Borba, H., 1977. Panstrongylus megistus leucofasciatus Lucena, 1959 e Rhodnius nasutus Stål, 1859 (Hemiptera: Triatominae) em Pernambuco, Brasil. Rev. Inst. Med. Trop. São Paulo 19, 332-334.

Monteiro, S., Kaz, L., 1994. Caatinga - Sertão Sertanejos. Alumbramentos Livroarte, Rio de Janeiro, 255 pp.

Nijhout, H.F., 2003. The control of body size in insects. Dev. Biol. 261, 1-9.

Quinn, G.P., Keough, M.J., 2002. Experimental design and data analysis for biologists. Cambridge University Press, Cambridge.

Romaña, C.A., Pizarro, J.C., Rodas, E., Guilbert, E., 1999. Palm trees as ecological indicators of risk areas for Chagas disease. Trans. Royal. Soc. Trop. Med. Hyg. 93, 594-595.

Sarquis, O., Borges-Pereira, J., Mac, Cord., Gomes, J.R., Cabello, T.F., Lima, P.H.M.M., 2004. Epidemiology of Chagas disease in Jaguaruana, Ceará, Brazil. I. Presence of triatomines and index of Trypanosoma cruzi infection in four localities of a rural area. Mem. Inst. Oswaldo Cruz 99, 263-270.

Wilks, S.S., 1932. Certain generalizations in the analysis of variance. Biometrics 24 471.

Wright, S., 1978. Evolution and the Genetics of Populations, Variability Within and Among Natural Populations, vol. 4. University of Chicago Press, Chicago. 